\title{
Proposal of Methodology and Calibration of Dynamometers for Quantification of Forces in Anchor Bolts
}

\author{
Miroslav Pástor ${ }^{1 *}$, František Trebuňa ${ }^{1}$, František Šimčák ${ }^{1}$, Marián Buršák ${ }^{2}$, Patrik Šarga ${ }^{1}$ and \\ Lubomír Gabáni ${ }^{3}$

\begin{abstract}
1 Technical University of Košice, Faculty of Mechanical Engineering, Department of Applied Mechanics and Mechatronics, Letná 9, 04200 Košice ${ }^{2}$ Technical University of Košice, Faculty of Metallurgy, Department of Materials Science, Park Komenského 11, 04385 Košice
\end{abstract} \\ ${ }^{3}$ U.S. Steel Košice s.r.ro, Vstupný areál U. S. Steel, 04454 Košice
}

\begin{abstract}
Miroslav Pástor, doc. Ing., PhD. (1975) is a associated professor of applied mechanics on the Department of Applied Mechanics and Mechatronics. In 2008 he received PhD. in the field of applied mechanics. In 2013 he habilitated in the area of applied mechanics. He is author of 2 monographs, 3 university textbook and more than 60 publications in journals and conference proceedings at Slovakia and abroad. He is co-author of important projects and engineering works. He made remarkable work on the building of laboratories and on publication of monographs and university textbook at the department. His professional and scientific orientation is oriented to experimental mechanics, prediction lifetime of structure, stress and strain analysis, photoelasticimetry. He is a member of Slovak Association of Mechanics by Slovak Academy of Sciences.
\end{abstract}

František Trebuña, Dr.h.c. mult. prof. Ing. CSc. (1947) is a professor of applied mechanics, Dean of the Faculty of Mechanical Engineering of Technical University of Košice. He is author of 12 monographs, 13 university textbook, special book publications, 12 university notebooks and more than 350 publications in journals and conference proceedings in Slovakia and abroad. He is also author of important projects and engineering works. His professional and scientific orientation is oriented to experimental and numerical methods of mechanics, prediction lifetime of structure, stress and strain analysis, photoelasticimetry, redistribution of stresses, modal analysis. He received several prizes at home and abroad. He received three honorary Doctor Honoris Causa (Dr.h.c.) including two from foreign universities for the development of applied mechanics and mechatronics and last year he received Honorary Doctorate of Letters (For the extraordinary contribution in the area of creation, development and publication activity in the scientific branches of applied mechanics and mechatronics), IBC Cambridge, England. At the beginning of 2014 he received State prize he got "Honour of Ludovit Štúr of the 2nd order". Prof. Trebuña is a member of several Scientific councils on technical universities in Slovakia and abroad and member of editorial boards of journals.

František Šimčák, prof. Ing. (Sc. (1947) is a professor of applied mechanics, Head of the Department of Applied Mechanics and Mechatronics. He is author of 8 monographs, 11 university textbook, 6 university notebooks and more than 250 publications in journals and conference proceedings in Slovakia and abroad. He is co-author of important projects and engineering works. He received several prizes due to his scientific results. His professional and scientific orientation is oriented to strength and stiffness analysis of thin-walled elements and structures, computational and experimental stress analysis of structural elements made of classical and composite materials, plastic properties of steel sheets and lifetime of structures. He is a member of Scientific council of the Faculty of Mechanical Engineering, Technical University of Košice.

Marián Buršák, prof. Ing., PhD. (1949) is a professor on the Department of Materials Science at Faculty of Metallurgy. He is author of 3 monographs, 3 university textbook and more than 130 publi- 
cations in journals and conference proceedings at Slovakia and abroad. He is co-author of important projects and engineering works. His professional and scientific interests are oriented to material engineering of metal and non-metal materials, limit states of materials, degradation processes in materials. He is a member of the Scientific council of the Faculty of Metallurgy, member of editorial boards of journals, Slovak Association of Metallurgy and Croatian Association of Metallurgy.

Patrik Šarga, Ing. PhD. (1979). He graduated in "Automation and Control in Mechanical Engineering" at Technical University of Košice in 2002. He was an internal PhD. student at the Department of Applied Mechanics and Mechatronics and in 2005 he defended his dissertation thesis in field of mechatronics. Nowadays he works as an assistant on the Department of Applied Mechanics and Mechatronics at the Faculty of Mechanical Engineering at Technical University of Košice. He is co-author of three books of lecture notes and more than 70 publications in journals and conference proceedings in Slovakia and abroad, e.g. Engineering Failure Analysis, Metalurgija. He has worked on several grant projects, research tasks and many projects solved for industry realized on the department.

Lubomír Gabáni, Ing. (1968). He graduated at the Faculty of Mechanical Engineering, Technical University of Košice in 1991. Since 1991 he works in the U.S.Steel Košice a.s. in manager positions relating to reparation works. Since November 2011 he is Team Manager Steelworks Maintenance Reliability.

Abstract: Anchor bolts in heavy machines of metallurgical plants are often, from the point of view of their carrying capacity, limiting factor in increasing productivity. This paper presents some possibilities of increasing strength of anchor bolts using numerical and experimental methods of mechanics. Proposed and verified procedures allow determining the actual stress states during tightening the anchor bolts and nuts and reduce dynamic loads in bolts as well as in operating machines.

Keywords: Anchor bolts, numerical and experimental methods of mechanics, dynamometer.

\section{Introduction}

Heavy equipment's of metallurgical plants (converters, casting pedestal, fans, etc.) are exposed during their operation to intensive dynamic loading. Pedestals of these devices are most often fastened with anchor bolts through which the dy- namic loading is transmitted to the ground. On the workplace of authors has been solved several tasks associated with increasing of carrying capacity of anchor bolts in heavy equipment of metallurgical plants [1-4].

In the paper is described methodology and realization of dynamometer calibration used for regulation of forces in anchor bolts of casting pedestal.

\section{Force states in anchor bolts}

In the analysis of stress relations in the anchor bolts is necessary to know the size of the prestress, as well as the size of the static and dynamic load in different working regimes of metallurgical equipment's. Distribution of forces in pre-stressed bolted connections with vanishing variable load, which occurred most frequently in the analyzed cases are shown in Fig. 1

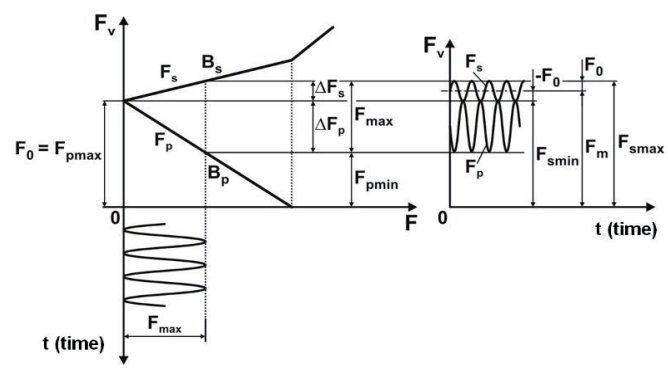

Fig. 1: Vanishing load in bolt connection with prestress.

During loading of bolt connection according to Fig. 1 the maximum force in a bolt is

$F_{s \max }=F_{0}+\Delta F_{s}=F_{0}+\frac{k_{s}}{k_{s}+k_{p}} \cdot F_{\max }$

and force amplitude $\Delta F_{s} / 2$ in bolt depends on bolt stiffness $k_{s}$ and stiffness of flange $k_{s}$.

Increasing ratio $k_{p} / k_{s}$ reduces the force amplitude in the bolt while bigger force $F_{0}$ in pre-stress is needed to ensure contact of connected parts. However, from the point of view of bolt fatigue safety this change has a positive effect [5-7]. Force $F_{0}$ in pre-stress of a bolt is caused by torque moment $M u$. In case that after long-term working is necessary to tight anchor bolts or if modernization of equipments is connected with necessity to tighten bolts due to possible change on bolts (rust, plastic deformation, lack of drawings of bolts in concrete foundations, etc.) it is difficult to de- 
termine dependency $F_{0}=F_{0}\left(M_{u}\right)$ or $F_{0}=F_{0}(p)$, where $p$ is pressure in corresponding tightening equipment producing tightening torque $M_{u}$ [8-10].

In the paper is proposed methodology of determination of axial force in bolts of casting pedestal by using of strain-gages that are applied on deformation body of the dynamometer. Axial forces in anchor bolts of carrying elements can reach high levels. Proposed dynamometers are used for determination of axial forces in anchor bolts with diameters $52 \mathrm{~mm}$ and $56 \mathrm{~mm}$, respectively, loaded by normal force reaching almost $350 \mathrm{kN}$. The magnitude of loading force was determined by superposition of forces resulting from pre-stress and increments of axial forces due to operation of casting pedestal (including dynamic forces). The dynamometer has to be able to measure such forces.

Deformation body of dynamometer for measurement of axial forces was proposed and optimized by the finite element method and its drawing is given in Fig. 2. The dimensions of dynamometer has to fulfill technical demands for its using in operation conditions, e.g. its height is defined by the space between anchor bolt and carrying part of casting pedestal that cannot be disassembled (operation measurement is realized in the time of capital repair of casting pedestal). The shape of deformation body was proposed to allow preservation of strain-gages against mechanical damage.

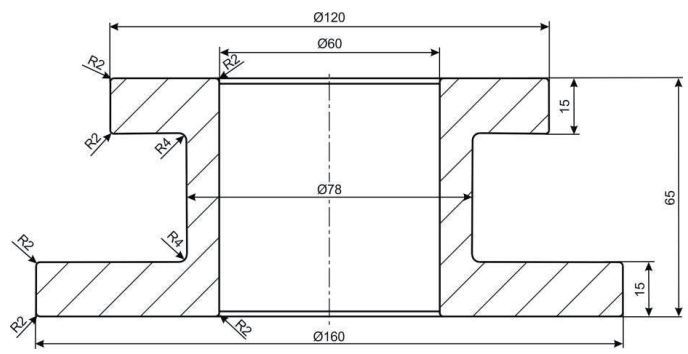

Fig. 2: Deformation body of dynamometer.

The boundary conditions defined for numerical analysis by the finite element method represent loading of dynamometer supported in bottom part by load created by tightening of nut.

In Fig. 3 is given the field of equivalent forces resulting from the finite element analysis of deformation body loaded by pressure which does not exceed load force $100 \mathrm{kN}$.

The magnitude of axial force $350 \mathrm{kN}$ leads to

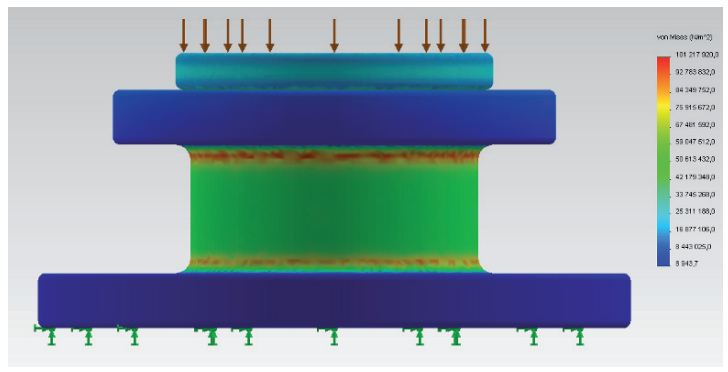

Fig. 3: Equivalent stresses under loading 100 kN.

the equivalent stress of magnitude approximately $210 \mathrm{MPa}$ in the location of strain-gages. On the basis of analysis of results gained by numerical modeling deformation bodies of dynamometers were produced made of material 12050. In Fig. 4 is shown deformation body of dynamometer.

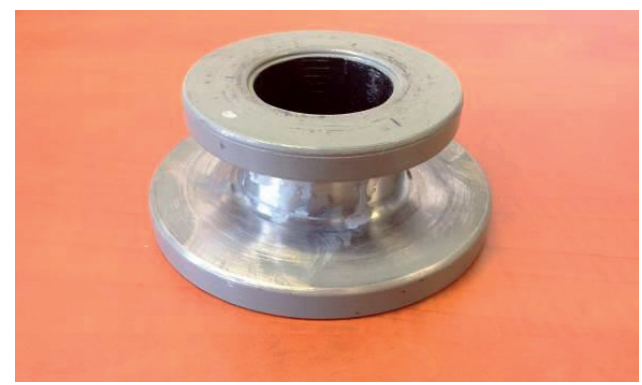

Fig. 4: Deformation body.

The calibration of dynamometers accomplished by strain-gages. On the deformation bodies were applied in four locations rotated by $90^{\circ}$, two straingage grids XY91-1/120 in bridge arrangement, in order to exclude influence of bending. Strain-gages and its arrangement on one deformation body of dynamometer is given on Fig. 5 .

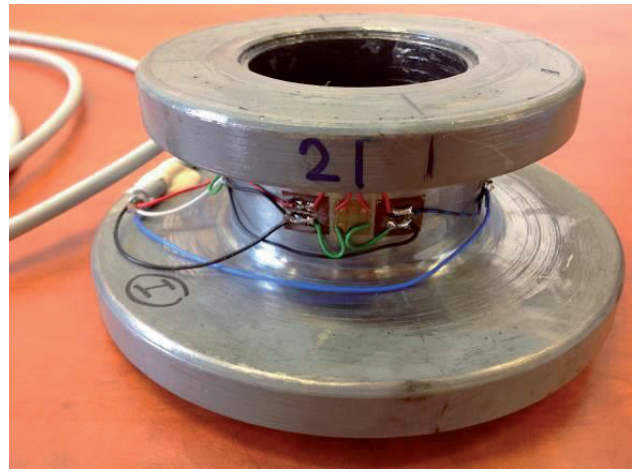

Fig. 5: Strain-gages applied on the deformation body of dynamometer. 
The calibration of proposed dynamometers was accomplished as follows. The most accurate calibration is a calibration in laboratory by using of hydraulic loading test machine where the load forces and corresponding strains are registered on straingage apparatus with given bridge arrangement. In Fig. 6 is a view to measurement chain for the calibration of dynamometers. It consists of hydraulic loading machine, deformation body of dynamometer and a strain-gage P3 produced by Vishay.

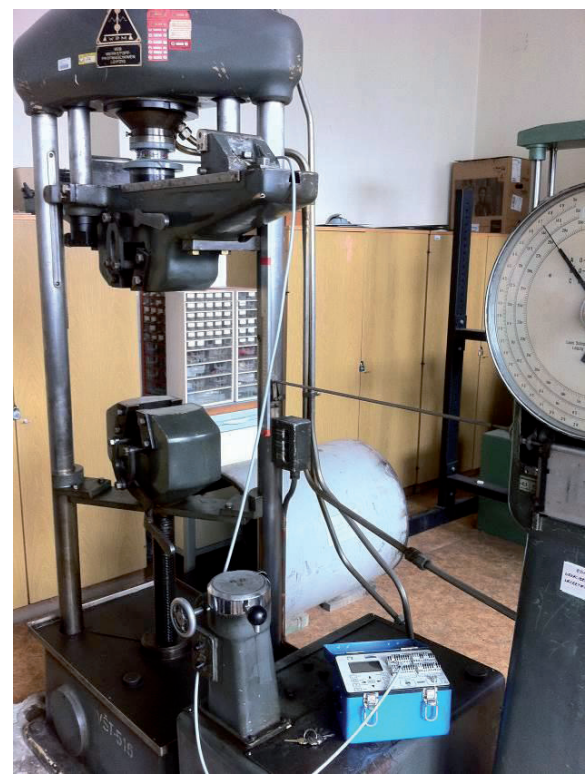

Fig. 6: Measurement chain for calibration of dynamometers

In Fig. 7 is given dynamometer positioned inside of grip cheeks of loading equipment.

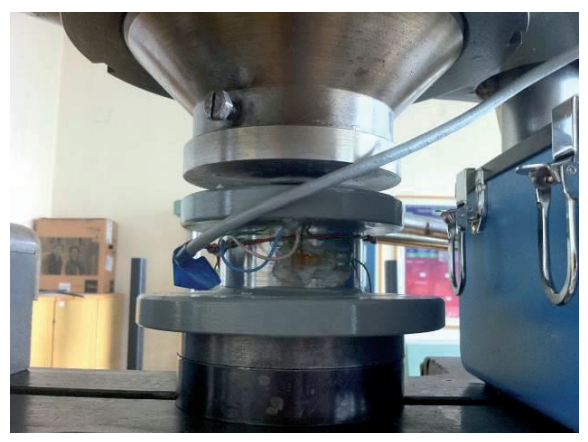

Fig. 7: Dynamometer inside of tension grips of test machine.

In Fig. 8 is shown deformation body of dynamometer in the process of compression by loading machine. For every dynamometer was realized repeated experimental measurements for deter- mination of dependencies between strains in deformation body and loading force. On the basis of given measurements, the calibration diagram for every deformation body was created, showing dependence of measured strain on the magnitude of force producing by loading machine, Fig.9. With respect to low sensitivity of loading machine in bottom part of measurement scale (delayed response to load force), the magnitudes were record by 50 kN. Repeated experimental measurement confirmed linear dependency of measured quantities which documents stress levels in dynamometer in elastic area.

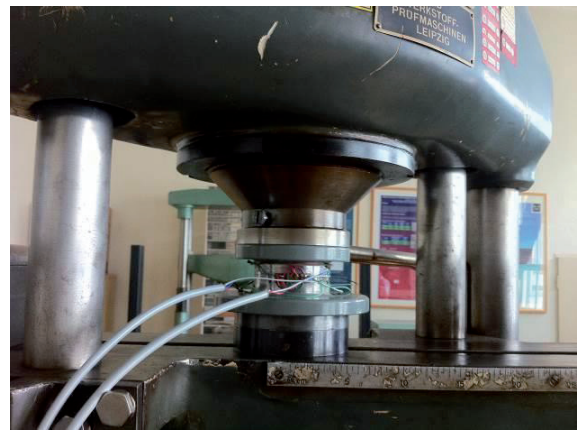

Fig. 8: Compression of dynamometer in test machine.

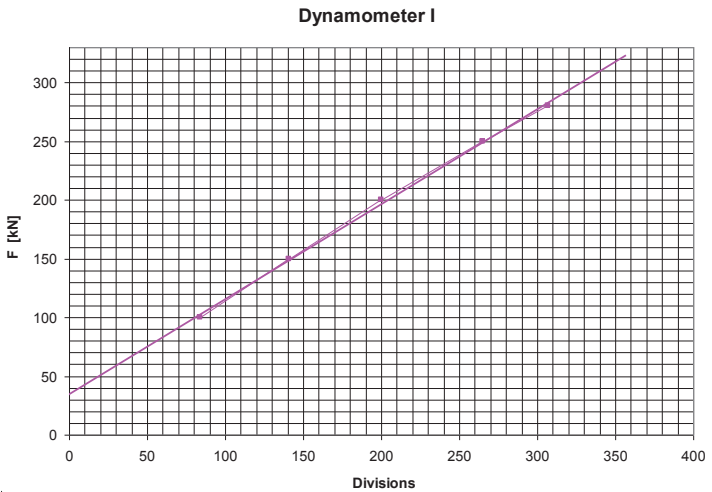

Fig. 9: Calibration diagram of dynamometer I.

Further calibration accomplished also in laboratories of Technical University of Košice determined dependency of compression pressure (tightening torque) adjusted on loading equipment Enerpac and produced axial force in the bolt, registered by deformation body of dynamometer. The calibration was realized by a system Enerpac which is used for tightening of anchor bolts of casting pedestal. The screws were lubricated and the type of lubrication mean is inhered in calibration diagram. 
In Fig. 10 is given measurement chain for determination of dependencies between axial force registered by dynamometer and pressure in tightening equipment Enerpac.

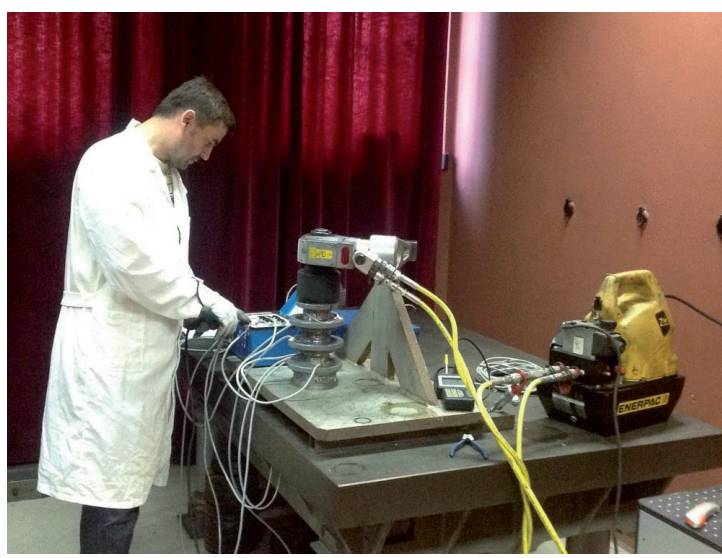

Fig. 10: Measurement chain.

Measurement chain consists of tightening machine Enerpac, deformation bodies of dynamometers and strain-gage apparatus P3 produced by Vishay.

Results of the measurements are diagrams of dependencies of quantities from strain-gage apparatus P3 (number of divisions on the scale) for the dynamometer and corresponding magnitude of axial force $\mathrm{F}$ in the bolt or pressure $\mathrm{p}$ in tightening equipment. In Fig. 11 is given calibration diagram for dynamometer II.

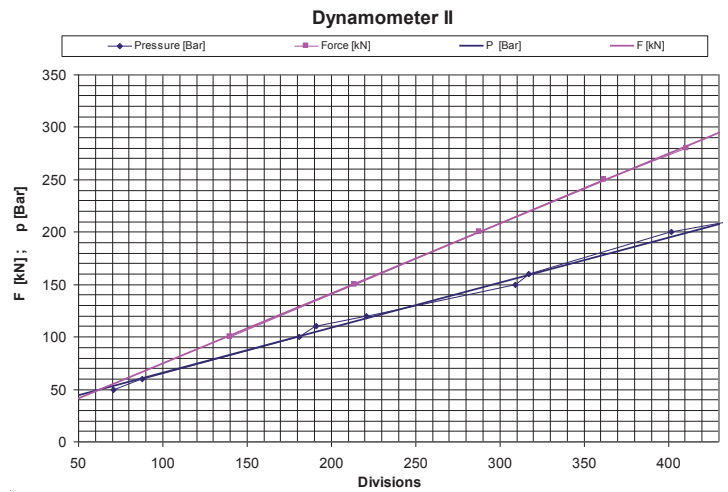

Fig. 11: Calibration diagram of dynamometer II.

Deformation bodies of dynamometers proposed by authors were after calibration used for determination of axial force in anchor bolts on casting pedestal (Fig. 12).

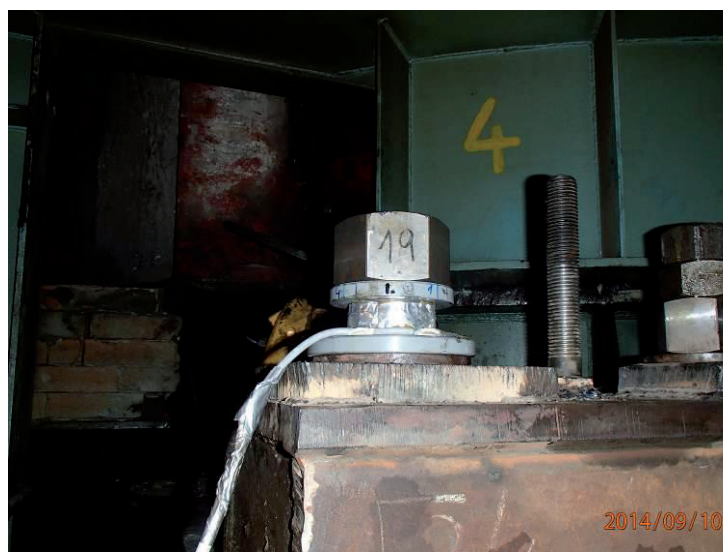

Fig. 12: View to dynamometer installed on anchor bolt of casting pedestal.

\section{Conclusion}

The results gained from the experimental measurements confirmed correctness of proposed methodology of determination of axial force in anchor bolt on the pressure invoked by tightening equipment Enerpac by using strain-gages on deformation body of dynamometer.

Because in most cases of anchor bolts, tightening was realized by dynamometers and new nuts with action of anchor bolts and foundations, for creation of necessary pre-stress was used directly determined pressure value in tightening equipment for every individual bolt. Even if there is some scattering in values of pre-stress, from calibration diagrams and verification of methodology is obvious that the differences do not reach $5 \%$.

\section{Acknowledgments}

This article was created with the support by project "University science park Technicom for innovative applications with the support of sciential technologies" (ITMS: 26220220182) and project VEGA 1/0937/12 Development of unconventional experimental methods for mechanic and mechatronic systems.

\section{References}

[1] Trebuňa, F., Šimčak, F., Bocko, J. (2009). Decreasing of vibration amplitudes of the converter pedestal by design changes and changes in prestress of the bolted joints, Engineering Failure Analysis, 16, p. 262-272

[2] Trebuňa, F. et al. (2000). Pevnostné posúdenie kotviacich skrutiek stojana ZPO I a ich spojenia so základom. SjF TU v Košiciach. 
[3] Trebuňa F. et al. (2009). Riešenie predlženia životnosti liacieho stojana s využitím záverov doterajších analýz a návrhy úprav pre predlženie životnosti liacieho stojana. SjF TU, Košice

[4] Trebuňa, F. et al. (2005). Vibration of converter pedestal, suggestions for possible structural modifications and their verification. SjF TU, Košice

[5] Kobayshi, A. S. (1993). Handbook on Experimental Mechanics, VCH Verlagsgesellschaft mbH, Weinheim, Germany.

[6] Ožbolt, J., Eligehausen, R., Periškić, G., Mayer, U. (2007). 3D FE analysis of anchor bolts with large embedment depths. In. Engineering Fracture Mechanics. Volume: 74, Issue: 1-2, P. 168-178, ISSN: 0013-7944

[7] Trebuňa, F., Šimčák, F. (2007). Príručka experimentálnej mechaniky. Typopress, Košice

[8] Trebuňa, F., Šimčák, F., Bocko, J., Trebuňa, P. (2010). Failure analysis of mechanical elements in steelworks equipment by methods of experimental mechanics. In: Engineering Failure Analysis. Vol. 17, no. 4 (2010), p. 787-801. - ISSN 13506307

[9] Trebuňa, F., Šimčák, F., Bocko (2009). Decreasing of vibration amplitudes of the converter pedestal by design changes and changes in prestress of the bolted joints. In: Engineering Failure Analysis. Vol. 16, no. 1, p. 262-272. - ISSN 13506307

[10] Delyová I. et al. (2014). Stress analysis of the thin-walled vessels. In: Applied Mechanics and Materials. Vol. 611, p. 273278. - ISSN 1660-9336

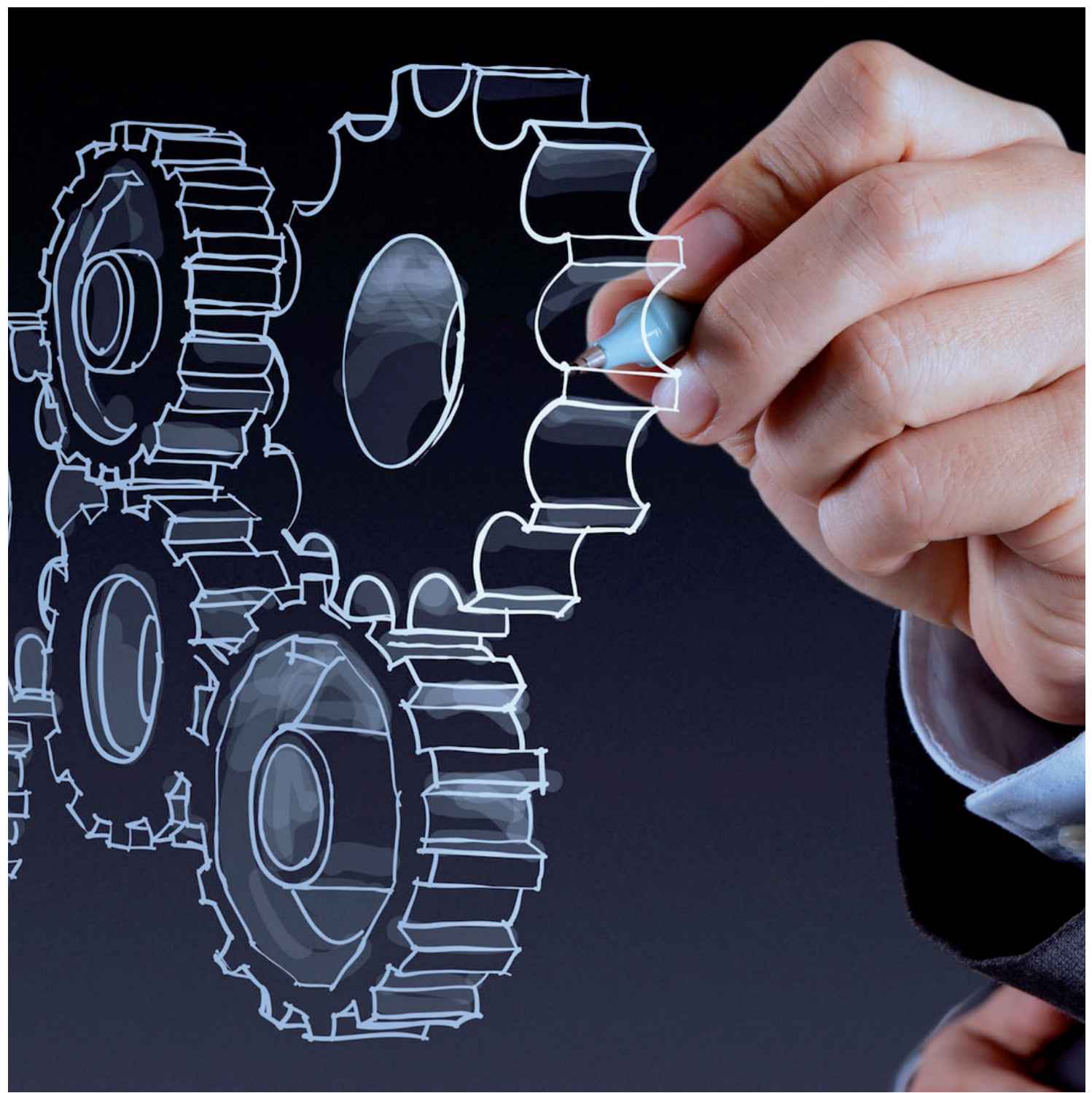

